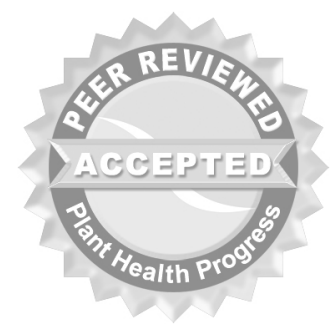

(C) 2010 Plant Management Network.

Accepted for publication 17 May 2010. Published 27 July 2010.

\title{
Characterization of a Peanut Leaf Spot of Unknown Etiology
}

\author{
Emily G. Cantonwine, Assistant Professor, Department of Biology, \\ Valdosta State University, Valdosta, GA 31698; Albert K. Culbreath, \\ Professor, Robert C. Kemerait, Associate Professor, and \\ Ronald D. Gitaitis, Professor, Department of Plant Pathology, \\ University of Georgia, Tifton, GA 31793
}

Corresponding author: Emily G. Cantonwine. egcantonwine@valdosta.edu

Cantonwine, E. G., Culbreath, A. K., Kemerait, R. C., and Gitaitis, R. D. 2010.

Characterization of a peanut leaf spot of unknown etiology. Online. Plant Health Progress doi:10.1094/PHP-2010-0727-01-RS.

\begin{abstract}
Irregular leaf spot (ILS) of peanut was first noticed in Florida during the late 1990 s. By 2000 , ILS was apparent throughout much of the southeastern peanut growing region of the United States. Experiments were conducted to identify the cause of ILS, characterize ILS development over time, and evaluate the effect of genotype, tillage, and applications of fungicides and bactericides on ILS. Severities of ILS were near maximum levels at 33 to 42 days after planting (DAP) and in decline by 56 DAP. Incidence of ILS was greater in the lower canopy than the upper canopy. In most cases, ILS intensities were greater in strip-tilled plantings than conventional-tilled plantings and in the peanut breeding line UF-99325 than the cultivar Georgia Green. No fungicide or bactericide treatment suppressed ILS intensity. Attempts to isolate pathogenic fungi or bacteria from ILS lesions were unsuccessful. Although a pathogen cannot be totally dismissed as the cause of ILS, it is likely that ILS is caused by an abiotic factor.
\end{abstract}

\section{I ntroduction}

Symptoms of a leaf spot of peanut (Arachis hypogaea L.), called irregular leaf spot (ILS), Florida leaf spot (2), and funky leaf spot (8), were first noticed in Florida during the late 1990s (8). Foliar lesions associated with ILS were similar to those of early leaf spot, caused by Cercospora arachidicola S. Hori (Figs. 1 and 2). One important difference was that ILS generally appeared well before the typical onset of early leaf spot, having been observed as early as 23 days after planting (DAP) (E. G. Cantonwine, unpublished data). Symptoms first appeared in the lower canopy and included brown lesions that were often surrounded by a yellow halo. Premature defoliation of these leaves was common (Fig. 1). In the upper canopy, ILS lesions had more irregular margins than typical early leaf spots (Fig. 2). Lesions of both canopies lacked signs of fungal fruiting bodies or sporulation. By 2000, ILS was affecting peanut fields throughout northern Florida and had been reported in Georgia, South Carolina, and parts of North Carolina (8).

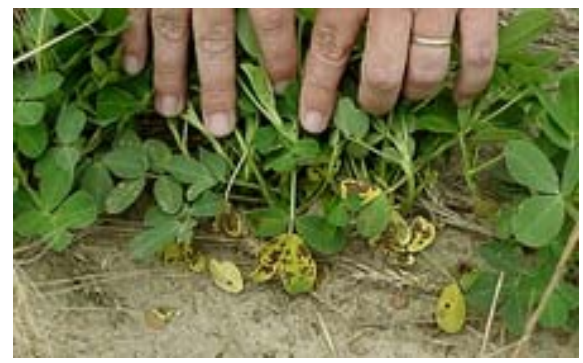

Fig. 1. Irregular leaf spot symptoms within the lower canopy of young peanut plants. 


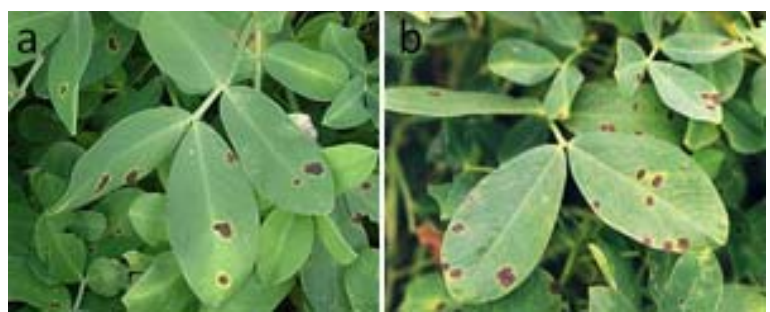

Fig. 2. Irregular leaf spot lesions (a) within the upper canopy of peanut plants compared to early leaf spot lesions (b) within the upper canopy.

Irregular leaf spot became a significant concern to some growers in Georgia in 2001 when it was mistaken as an early onset of early leaf spot which can cause significant yield loss if not controlled (6). Many growers began fungicide programs earlier or made extra applications for control of ILS. The increase of fungicide use had no affect on the intensity of ILS, which led to concerns of fungicide failure. These concerns subsided as the season progressed without increases in incidence of ILS or unmanageable early leaf spot. However, grower concerns about the confusing symptoms of ILS and apparent lack of control remained.

The lack of information prompted studies to identify the cause of ILS, characterize its development over time, and to evaluate the effects of genotype, tillage, and application of fungicides and bactericides on ILS development. Initial observations of ILS have suggested that peanut genotypes differed in sensitivity to ILS (A. K. Culbreath, unpublished data), and it was more severe in strip-tilled than conventional-tilled plantings (5).

\section{Evaluating Epidemics in the Field}

Field experiments were conducted at the University of Georgia, Coastal Plain Experiment Station, Tifton, GA in 2002, 2003, and 2004 to determine ILS intensity over time and the effects of peanut genotype, tillage system, and pesticide chemistry. Soil type was a Tifton loamy sand. Fields were planted to cotton the previous year and peanut two years prior. Winter wheat was planted as a cover crop the previous fall.

In 2002 and 2003, the experimental design was a randomized split-split plot with three replications. Treatments consisted of combinations of two tillage treatments (main plots), two genotypes (subplots), and six or eight fungicide/ bactericide treatments (sub-subplots). In 2004, the experimental design was a split-plot with four replications of tillage treatments in main plots and genotypes in sub-plots. Tillage treatments were conventional- and striptillage. In conventional-tillage, the winter cover crop was mowed and disked twice prior to deep turning ( 20 to $25 \mathrm{~cm}$ deep) with a switch plow, and rows bedded with a disk bedder. In strip-tillage, a subsoil shank attached to a tworow strip-till implement (Kelley Manufacturing Co., Tifton, GA) was used to loosen the plow pan at $33 \mathrm{~cm}$ beneath the row, while the implement prepared tilled strips approximately $20 \mathrm{~cm}$ wide. Peanut genotypes included the cultivar Georgia Green and breeding line UF-99325, which had previously been observed to have a high incidence of ILS. Plots consisted of two, 91-cm-spaced rows that were $6 \mathrm{~m}$ long and replications were separated by 2.4-m alleyways. Peanut seed were planted in late May, and no in-furrow insecticides were applied at planting.

In 2002, pesticide treatments consisted of a non-sprayed control and five fungicide programs where the first two applications were: (i) $1.26 \mathrm{~kg}$ ai/ ha chlorothalonil (Bravo Weatherstik 720 F, Syngenta Crop Protection Inc, Greensboro, NC); (ii) $0.22 \mathrm{~kg}$ ai/ ha tebuconazole (Folicur 3.6 F, Bayer CropScience, Research Triangle Park, NC); (iii) $0.28 \mathrm{~kg}$ ai/ ha thiophanatemethyl (Topsin M 70 WP, Cerexagri, Inc., King of Prussia, PA); (iv) 0.064 kg ai/ ha trifloxystrobin $+0.064 \mathrm{~kg}$ ai/ ha propiconazole (Stratego, Bayer CropScience, Research Triangle Park, NC); and (v) $0.11 \mathrm{~kg}$ ai $/$ ha pyraclostrobin (Headline, BASF, Research Triangle Park, NC). In 2003, the same fungicide treatments were employed, plus two additional programs with bactericidal activity; where the first two applications were: (vi) $1.2 \mathrm{~kg}$ ai/ ha copper hydroxide (Kocide 2000, DuPont Crop Protection, Wilmington, DE); and 
(vii) $0.38 \mathrm{~kg}$ ai/ ha streptomycin sulfate (Agri-mycin, Syngenta Crop Protection Inc, Greensboro, NC). The first application was made 24 DAP with additional applications at 14-day intervals. Tebuconazole was used in all programs for applications 3 through 7. For the treatment that consisted of tebuconazole in the first two applications, the number of applications of tebuconazole and total amount of ai applied exceeded that specified on the Folicur label and by the University of Georgia Extension Service (4). Fungicides were applied using a multiple-boom tractor-mounted $\mathrm{CO}_{2}$-propellant sprayer in 115 liters of water per ha at $345 \mathrm{kPa}$. Each boom was equipped with three, D3-23 hollow-cone spray nozzles per row. Post-emergence herbicides and insecticides were applied to all plots based on recommendations by the University of Georgia Extension Service (7).

Severity of ILS per plot was estimated in 2002 and 2003 using a 1 to 7 scale where 1 = no ILS lesions; 2 = very few ILS lesions in lower canopy; 3 =few ILS lesions in lower canopy leaves, very few in upper canopy; $4=$ moderate number of ILS lesions in upper canopy, and 5\% defoliation; $5=$ ILS lesions evident, and $20 \%$ defoliation; $6=$ ILS lesions evident, and $50 \%$ defoliation; and $7=$ ILS lesions evident and $>50 \%$ defoliation. Ratings 1 to 6 of the ILS scale are directly comparable to levels 1 to 6 on the Florida 1 to 10 scale for early and late leaf spot of peanut (3). Evaluations of severity began when ILS was apparent in the Georgia Green conventional-tillage plots while scouting, 42 DAP in 2002 and 35 DAP in 2003, and continued at 7-day intervals until early leaf spot severity began to interfere with assessments (77 DAP in 2002, 78 DAP in 2003). Plants were in the R1 (beginning bloom) or R2 (beginning peg) stages of development (1), and no other disease symptoms were apparent except for low levels of pepper spot and leaf scorch, caused by Leptosphaerulina crassiasca. Pepper spot and leaf scorch were not believed to have contributed significantly to defoliation. Mean disease severity by assessment date was plotted for the tillage-genotype treatments across fungicide treatments and replications. Area under severity levels (AUSL) of ILS during the assessment period was computed for each plot using the method reported to compute area under the disease progress curve (10).

Because symptoms occurred similarly across plants within plots, incidence of ILS was evaluated for each plot by evenly sampling 26 leaves from the upper half of the peanut canopy and 26 leaves from the lower half of the peanut canopy. Evaluations were conducted when ILS was first apparent in the Georgia Green conventional-tillage plots while scouting, 35 DAP in 2003 and 33 DAP in 2004. Leaflets with ILS lesions or that were defoliated were recorded as affected by ILS.

Effects of tillage, genotype and pesticide treatment were examined using the Proc MIXED procedure with ddfm = satterth option on the model statement (SAS v.8.3, SAS Institute Inc., Cary, NC). Fisher's Protected LSD values were computed using standard error and t-values of adjusted degrees of freedom. When an interaction was significant, the LSD was adjusted to reflect use of the interaction term as a source of error. If the F-test for the main effect using the significant interaction showed the main effect to be significant, the main effect means were presented; otherwise, only the interaction means were presented.

\section{Severity of I rregular Leaf Spot and Treatment Effects in the Field}

Statistical analyses were done by year due to significant interactions of year with one or more main effects. Because there were no significant interactions with fungicide ( $\mathrm{P}>0.17)$, the progression of ILS severity for each genotypetillage treatment are shown across fungicide treatment and replication (Fig. 3). Severities of ILS were near their highest levels at the first assessment date each year, and fluctuated only slightly or declined across the evaluation period for all treatments. This pattern suggests that ILS is caused by a factor that is limited in opportunity as the season continues. A similar pattern was observed for ozone injury of winter barley (12). Although new lesions were observed on young, newly expanded leaves as late as September each year, additional defoliation was not noticeable for plants after $60 \mathrm{DAP}$. The optimum time to assess treatment effects on ILS was between 33 and 56 DAP. 

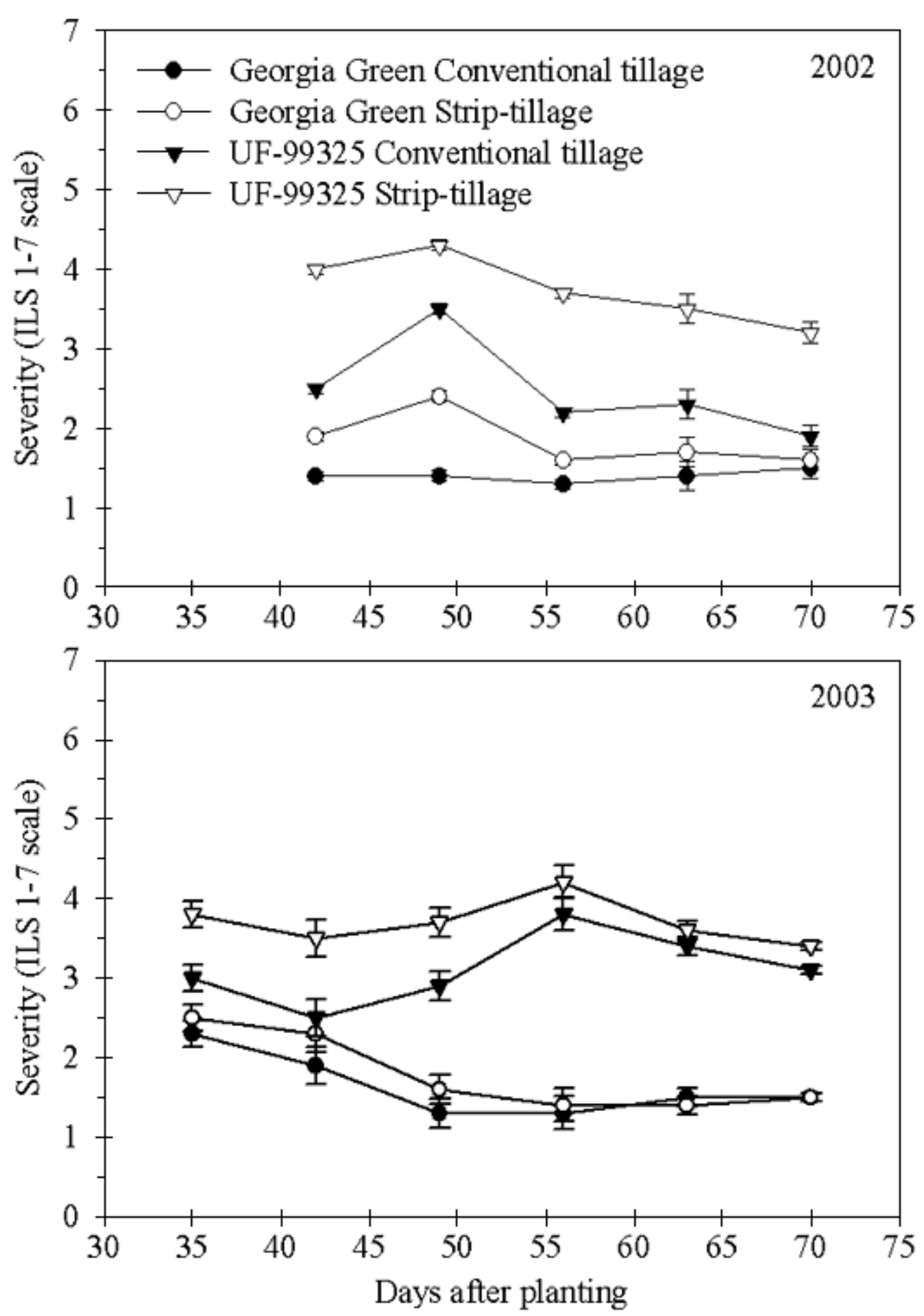

Fig. 3. Irregular leaf spot (ILS) severity ratings over time for Georgia Green and UF-99325 in conventional tillage and in strip-tillage in 2002 and 2003. Ratings at each date are pooled across fungicide treatments and replications.

Trifloxystrobin + propiconazole treatment and pyraclostrobin alone reduced AUSL values compared to the non-sprayed control in 2002 ( $\mathrm{P}<0.05)$, but the effect was small and not observed in 2003 ( $\mathrm{P}=0.98$ ) (Fig. 4). There was not a sufficient response to the fungicides or bactericides to suggest that ILS is caused by a fungus or bacterium. 

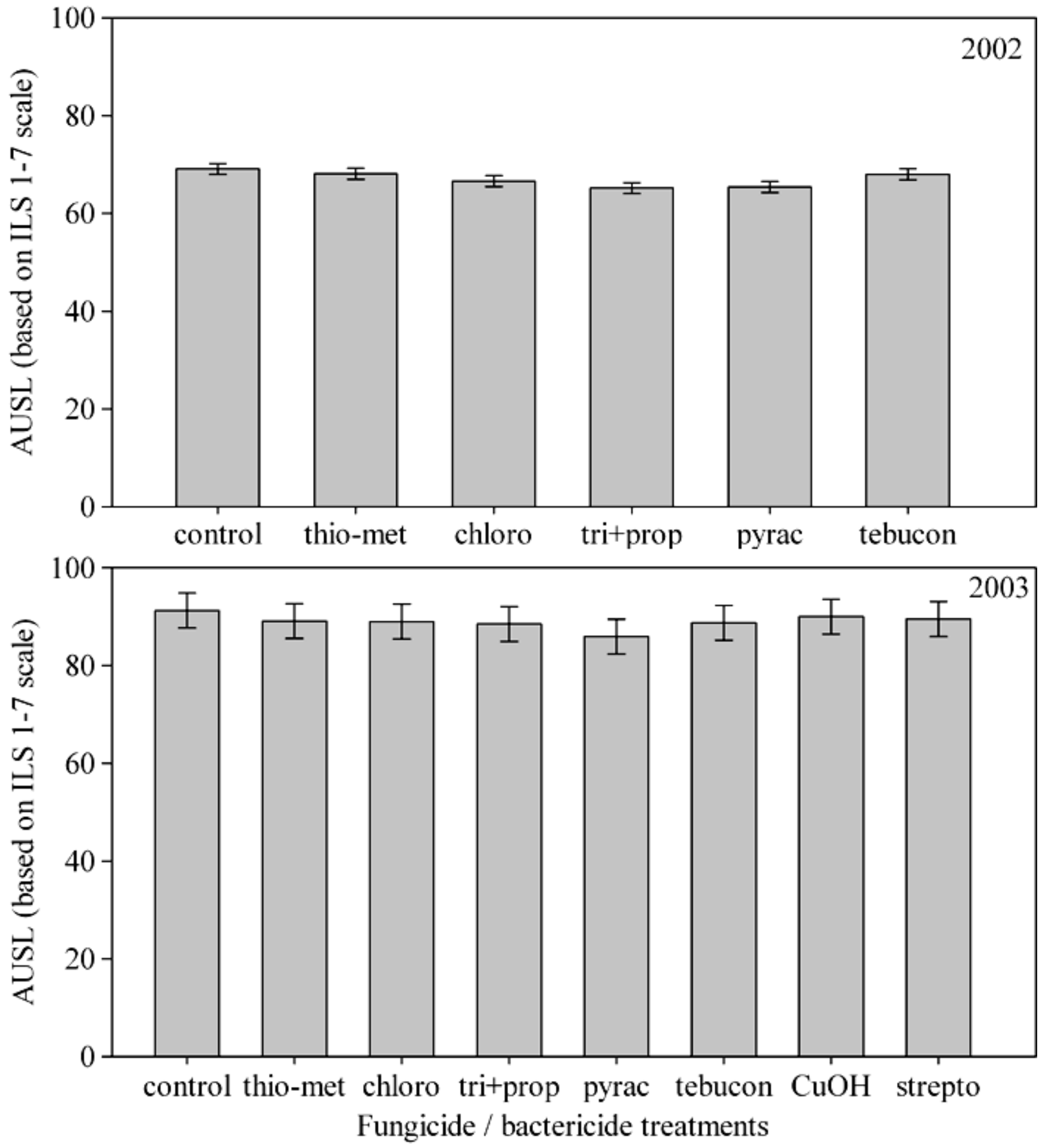

Fig. 4. Effect of fungicide treatments - non-treated control (control), thiophanate-methyl (thio-met), chlorothalonil (chloro), trifloxystrobin + propiconazole (tri+prop), pyraclostrobin (pyrac), and tebuconazole (tebucon) - and bactericide treatments - copper hydroxide $(\mathrm{CuOH})$ and streptomycin sulfate (strepto) - on area under severity levels (AUSL) of irregular leaf spot (ILS) in 2002 and 2003. Least square means from Proc MIXED across genotype and tillage treatments.

Incidence was higher in the lower canopy than the upper canopy for all treatments (Table 1). ILS incidence and AUSL were numerically or statistically higher in strip-tilled than conventional-tilled plots and higher for UF-99325 than Georgia Green (Table 1). Lower canopy incidence and ILS 1 to 7 ratings are good measures of ILS intensity. 
Table 1. Effect of peanut genotype and tillage on irregular leaf spot (ILS) incidence and area under severity levels (AUSL) of ILS in 2002-2004.

\begin{tabular}{|c|c|c|c|c|}
\hline \multirow{2}{*}{\multicolumn{2}{|c|}{ Year/ factor/ level }} & \multicolumn{2}{|c|}{ I ncidence (\%) } & \multirow[b]{2}{*}{ AUSL $^{W}$} \\
\hline & & Upper canopy ${ }^{\vee}$ & Lower canopy ${ }^{\vee}$ & \\
\hline \multirow{8}{*}{$2002^{x}$} & \multicolumn{4}{|l|}{ Genotype } \\
\hline & Georgia Green & - & - & 45.3 \\
\hline & UF-99325 & - & - & 88.6 \\
\hline & F- and P-values & - & - & $F=2963, P<0.01$ \\
\hline & \multicolumn{4}{|l|}{ Tillage } \\
\hline & Conventional till & - & - & 54.7 \\
\hline & Strip-till & - & - & 79.2 \\
\hline & F- and P-values & - & - & $F=940, P<0.01$ \\
\hline \multirow[t]{8}{*}{$2003^{y}$} & \multicolumn{4}{|l|}{ Genotype } \\
\hline & Georgia Green & 1.7 & 15.8 & 59.2 \\
\hline & UF-99325 & 2.5 & 37.6 & 118.9 \\
\hline & F- and P-values & $F=1.7, P=0.19$ & $F=24.4, P<0.01$ & $F=674, P<0.01$ \\
\hline & \multicolumn{4}{|l|}{ Tillage } \\
\hline & Conventional till & 1 & 22.6 & 81.4 \\
\hline & Strip-till & 3.2 & 30.9 & 96.8 \\
\hline & F- and P-values & $\mathrm{F}=12.0, \mathrm{P}<0.01$ & $F=3.6, P=0.06$ & $\mathrm{~F}=44.9, \mathrm{P}<0.01$ \\
\hline \multirow[t]{8}{*}{$2004^{z}$} & \multicolumn{4}{|l|}{ Genotype } \\
\hline & Georgia Green & 8.9 & 22.4 & - \\
\hline & UF-99325 & 11.1 & 43.6 & - \\
\hline & $\mathrm{F}$ - and P-values & $F=2.0, P=0.20$ & $\mathrm{~F}=30.1, \mathrm{P}<0.01$ & \\
\hline & \multicolumn{4}{|l|}{ Tillage } \\
\hline & Conventional till & 2.3 & 17.6 & - \\
\hline & Strip-till & 18.8 & 48.4 & - \\
\hline & $\mathrm{F}$ - and P-values & $\mathrm{F}=67.8, \mathrm{P}<0.01$ & $F=63.08, P<0.01$ & \\
\hline
\end{tabular}

Estimate of the standard error $=(\mathrm{F} \text {-value } / 2)^{1 / 2}$.

$\checkmark$ Least square means, F-values and P-values from Proc MIXED of ILS incidence from 26 leaves.

${ }^{\mathrm{w}}$ Least square means, F-values and P-values of area under severity levels using the ILS scale.

$x$ Based on ILS 1 to 7 assessment ratings recorded weekly 42 to 70 DAP.

$y$ Percent incidence of leaflets affected by ILS 35 DAP. AUSL based on ILS 1 to 7 assessments recorded weekly 35 to 70 DAP.

z Percent incidence of leaflets affected by ILS 33 DAP.

\section{I nvestigations of the Cause of I LS}

Non-sprayed peanut leaves with ILS symptoms were examined at each assessment date and near the end of the growing season for fungal fruiting structures and spores, and yearly for bacterial streaming. Green tissues along the edge of ILS lesions were used to isolate associated fungi and bacteria.

Attempts to isolate bacteria associated with ILS were conducted in August 2002 and J une 2003. Leaf tissues with ILS symptoms were submerged in approximately $1 \mathrm{ml}$ phosphate buffer and saline (PBS) in a sterile Petri dish, finely macerated with a razor blade, and allowed to sit for $10 \mathrm{~min}$. The suspension was then streaked onto nutrient agar and King's medium B agar and incubated for 36 to $48 \mathrm{~h}$ at $28^{\circ} \mathrm{C}$. Resulting bacterial colonies were examined for growth patterns consistent of a pathogen, including smooth colonies that are yellow, white, or flesh-colored on nutrient agar, fluorescent colonies on King's medium B agar under ultraviolet light (9), and for both media, colonies in high numbers in the mass streak and within the 4th quadrant of a streaked plate (11). 
Fungal isolations were conducted in 2002, 2003, and 2004. Tissue samples were surface sterilized with $0.6 \%$ sodium hypochlorite for 0.25 to 10 min rinsed in sterile water, and placed on water agar. After 1 to 14 days, if any fungal mycelia developed, they were transferred to potato dextrose agar (PDA), PDA amended with 5 ppm chlorothalonil, mycrophylla agar, or V8 juice agar. Multiple media were utilized to optimize isolation of potential fungal pathogen candidates. Petri dishes were wrapped with Parafilm and stored at room temperature $\left(20\right.$ to $\left.23^{\circ} \mathrm{C}\right)$. Cultures were examined weekly for sporulation and other diagnostic characteristics for at least one month. Sporulating colonies that were isolated more than once were identified to genus.

In 2003 and 2004, pathogenicity tests were conducted for all sporulating isolates and the most frequently isolated non-sporulating isolates to fulfill Koch's postulates. Plants of UF-99325 grown in the greenhouse for 8 or more weeks were mist inoculated using an atomizer with a $0.005 \%$ Tween 20 suspension that included spores and/ or mycelia from each selected isolate. Spores and mycelium were from 10- to 14-day-old cultures of isolates on PDA. Plants were maintained in a mist chamber for $48 \mathrm{~h}$ and then returned to the greenhouse where they were examined for ILS symptoms for 6 weeks. The experiment was replicated three times and conducted twice.

\section{Observations of Potential Causal Agents}

There was no evidence of bacterial streaming or fungal reproduction on ILS lesions collected throughout the assessment periods. Late in the growing season, after early leaf spot epidemics were well established, approximately 10\% of lesions collected as suspected ILS were found to be early leaf spot after close examination; the remaining were identified as ILS. The confusion resulted by early leaf spots that were irregularly shaped, similar to the ILS lesions shown in Figure 2a and some of the early leaf spot lesions in Figure 2b.

The fungal isolates evaluated in pathogenicity tests belonged to the genera Alternaria, Cochliobolis, Lophotrichus, and Bipolaris. None of the inoculations resulted in symptoms of ILS. Relatively few bacteria were isolated from ILS lesions and only a few single colonies isolated in the area of a mass streak. Due to low densities in the mass streak, these bacteria were not believed to have a pathogenic nature and were not included in pathogenicity tests.

\section{Recommendations}

Because fungicides and bactericides did not suppress ILS epidemics, practitioners should verify the cause of leaf spot before making changes to spray programs with a proven record of success. Observation of the presence or lack of sporulation by C. arachidicola on the top surface of the lesion, either in the field or from symptomatic leaves placed in a moist chamber, is the recommended method of verification. Verifying the cause of leaf spot is also important for plant breeders evaluating disease resistance. UF-99325 has better resistance to early leaf spot than Georgia Green (2). The optimum time to evaluate treatment effects on ILS intensity is between 33 and 56 DAP. Later assessment dates may be confounded by an emerging early leaf spot epidemic. The 1 to 7 scale was an easy method of ILS assessment and distinguished treatment effects in this study.

\section{Acknowledgments}

The authors thank Michael Heath, Sara Gremillion, and Allison McKeown for field assistance, Dr. D. W. Gorbet for seed of UF-99325, and Benjamin G. Mullinix for statistical advisement.

\section{Literature Cited}

1. Boote, K. J . 1982. Growth stages of peanut (Arachis hypogaea L.). Peanut Sci. 9:3540.

2. Cantonwine, E. G. 2005. The use of genetics and cultural practices to suppress foliar diseases of peanut and reduce fungicide requirements. Ph.D. thesis, Univ. of Georgia, Athens, GA. 
3. Chiteka, Z. A., Gorbet, D. W., Shokes, F. M., Kucharek, T. A., and Knauft, D. A. 1988. Components of resistance to late leaf spot in peanut: I. Levels of variabilityimplications for selection. Peanut Sci. 15:25-30.

4. Kemerait, R. C., Brenneman, T. B., and Culbreath, A. K. 2002. Peanut disease control. Pages 106-107 in: Georgia Pest Control Handbook. P. Guillebeau, ed. Coop. Ext. Special Bull. 28, Univ. Georgia, Athens, GA.

5. Monfort, W. S., Culbreath, A. K., Stevenson, K. L., Brenneman, T. B., Gorbet, D. W., and Phatak, S. C. 2004. Effects of reduced tillage, resistant cultivars, and reduced fungicide inputs on progress of early leaf spot of peanut (Arachis hypogaea). Plant Dis. 88:858-864.

6. Nutter, F. W. J., and Shokes, F. M. 1995. Management of foliar diseases caused by fungi. Pages 65-74 in: Peanut Health Management. American Phytopathological Society, St. Paul, MN.

7. E.P. Prostko, Editor. 2003. 2003 Peanut Update. Coop. Ext. Serv. Pub. No. CSS-030105. Univ. of Georgia, Athens, GA.

8. Rood, M. A. 2004. "Funky" leaf spot. The Peanut Farmer, April, 2004, 16-17.

9. Schaad, N. W., J ones, J. B., and Chun, W. Editors. 2001. Laboratory Guide for Identification of Plant Pathogenic Bacteria, 3rd Edn. American Phytopathological Society Press, St. Paul, MN.

10. Shaner, G., and Finney, R. E. 1977. The effect of nitrogen fertilization on the expression of slow-mildewing resistance in Knox wheat. Phytopathology 67:10511056.

11. Stall, R. E.. and Cook, A. A. 1966. Multiplication of Xanthomonas vesicatoria and lesion development in resistant and susceptible pepper. Phytopathology 56:11521154.

12. Wu, Y.-X., and von Tiedemann, A. 2004. Light-dependent oxidative stress determines physiological leaf spot formation in barley. Phytopathology 94:584592. 